\title{
Реформа индонезийской разведки: Нынешние вызовы и возможности создания демократич- ной профессиональной разведки
}

\section{Мурти Макарим А.}

Исполнительное бюро Президента Республики Индонезия, https://ksp.go.id/en/index.html

\begin{abstract}
Аннотация: В статье описана динамика реформирования индонезийской разведки от партизанской разведки во время революции после провозглашения независимости в 1945 г. до разведки авторитарного государства при режиме «Нового порядка» после 1965 г. и эпохи реформы разведки после реформаторского движения 1998 г. В последнее время вызовы индонезийских разведслужб сместились от потребности в законодательстве и политической стратегии в сторону необходимости демократической позиции разведки и способности противодействовать новым угрозам безопасности. Еще одним вызовом является конкуренция между службами военной, полицейской и стратегической разведки, которые все ориентированы на внутренние угрозы безопасности и внутренние разведывательные операции. Внутренние угрозы составляют весьма спорную область деятельности, «серые» зоны угроз для обороны, безопасности и разведки.
\end{abstract}

Ключевые слова: реформа разведки, военные, Новый порядок, Сухарто, BIN, Covid-19, пандемия.

\section{Вступление}

“Только для ваших глаз" 1

3 июля 2020 г. Президент Джоко Видодо (Джокови) подписал Президентский указ № 73 от 2020 г. о Министерстве по координации вопросов политики, права и безопасности (Kementerian Koordinator Bidang Politik Hukum dan Keamanan, Kemenkopolhukam). Интересно, что этот Президентский указ

1 Надпись на входе в Государственное разведывательное агентство (BIN) в Джакарте. 
ликвидировал координационные функции Министра в отношении Государственного разведывательного агентства (Badan Intelijen Negara, BIN), которые регламентировались Президентским указом № 43 от 2015 г. Таким образом, Президент - единственный клиент и непосредственный руководитель всех операций и институтов этого индонезийского агентства стратегической разведки.

Травма общества от чрезвычайных «полномочий» разведки, особенно военной разведки, обеспечивавшей контроль над обществом и политической системой, еще не полностью прошла. В стране, испытавшей 32 года авторитарного правления «Нового порядка» (Orde Baru) (1965-1998), организация разведслужб в правительственных министерствах и ведомствах остается важным вопросом. Для поколения, помнящего общественно-политическую атмосферу той эпохи, строгое и нетерпимое отношение к злоупотреблению властью, основными обязанностями и функциями разведки абсолютно и не подлежит обсуждению.

Одним из факторов появления чрезвычайных «полномочий» стратегической разведки был полный контроль разведки Президентом Сухарто при «Новом порядке». Без демократической системы сдерживаний и противовесов и имея олигархическое правительство при поддержке военных и бизнесменов, приближенных к власти, Президент Сухарто использовал разведку для защиты не только интересов безопасности государства, но и политических и экономических интересов себя лично и своей семьи.

«Возвращение» Президенту полного контроля над BIN воскресило воспоминания и опасения возможного «злоупотребления» разведкой в политических интересах правительства, особенно в разгар нынешней пандемии Covid-19, когда Президент имеет право принимать быстрые, непопулярные и чрезвычайные политические меры, включая использование вооруженных сил и разведки для поддержки мер борьбы с угрозой пандемии Covid-19. Опасения вызвала функция BIN как инструмента политических интересов Президента.

Правительство парировало эти вопросы и обвинения. «BIN находится в прямом подчинении президента, потому что президенту непосредственно нужны результаты деятельности разведки» - заявил Министр-координатор по вопросам политики, права и безопасности Махфуд (Mahfud) в своем официальном твиттере 18 июля 2020 г. ${ }^{2}$ Это соответствует роли Президента как единственного клиента BIN. Будучи официально отстраненным от координации согласно Указа, Махфуд тем не менее подчеркнул, что его министерство все же могло запрашивать информацию у BIN. «Как министр, я всегда получаю информацию от главы BIN и часто прошу BIN выступить с докладом на министерских совещаниях». ${ }^{3}$

2 CM. https://nasional.kompas.com/read/2020/07/20/09300611/kini-di-bawah-presidenini-sejarah-singkat-bin?page=all.

3 CM. https://nasional.kompas.com/read/2020/07/19/11344241/bin-tak-lagi-di-bawahkemenko-polhukam-ini-penjelasan-mahfud-md. 
В этой статье мы коротко вспомним историю изменений в стратегической разведке Индонезии после ее создания и проанализируем нынешнее состояние политической демократизации в целом и реформы разведки в частности после 1998 г. Статья ответит на вопросы по поводу отступления от демократии при полном контроле президента над BIN. Изложенные здесь взгляды - сугубо личные и не связаны с мнением или позицией каких-либо правительственных ведомств. ${ }^{4}$

\section{Разведка после провозглашения независимости в 1945 году}

История индонезийской разведки развивалась параллельно с историей революции после Декларации независимости (Proklamasi Kemerdekaan) 17 августа 1945 г. Талантливые агенты разведки, «рассеянные» среди обученной японскими военными молодежи в 1943 г., были объединены в силы стратегической разведки, чьей главной задачей была защита независимости от нападения Союзников и голландцев, желавших вернуть себе контроль над Индонезией.

«Основателем» стратегической разведки Индонезии, сейчас известной как BIN, считается Зулкифли Лубис (Zulkifi Lubis), родившийся в Банда-Ачехе 26 декабря 1923 г., офицер, бывший в 1955 г. Начальником штаба Армии. Лубис - выпускник Школы военной разведки Накано, созданной японскими оккупантами в 1943 г. [в городе Тангеранг, провинция Бантен], и лучший выпускник первого класса школы. Из 40 бывших бойцов «защитников родины» (Pembela Tanah Air, PETA), сформированных японскими военными, Лубис в августе 1945 г. создал первую разведслужбу Республики Индонезия под названием Специальное агентство (Badan Istimewa). ${ }^{5}$

Лубис имел опыт разведывательных операций после досрочного выпуска из Школы военной разведки Накано. В 1944 г. он работал в японском региональном разведывательном центре в Сингапуре. Он много учился и участвовал в японских разведывательных операциях войны в Азии и покорения Индокитая. Поэтому когда Индонезия в августе 1945 г. стала независимой, Лубис, которому было 19, когда он поступил в школу разведки, был одним из бывших японских военных в Индонезии, имевшим больше боевого опыта разведки, чем кто бы то ни было в Индонезии. Новой стране нужна была разведка для защиты независимости, что и отражено в названии Badan Istimewa. Лубис быстро обучил первых 40 сотрудников этого агентства, которые все прошли обучение японскими военными, принципам

4 Исследования реформ индонезийской разведки делят изменения в разведке на четыре периода, а именно: 1) Период обеспечения военных операций (19451958); 2) Период обеспечения реализации политической стратегии (1959-1965); 3) Период поддержки режима; и 4) Период поддержки восстановления безопасности. См. Ali A. Wibisono, "Reformasi Intelijen dan Badan Intelien Negara," in Panduan Pelatihan Tata Kelola Sektor Keamanan untuk Organisasi masyarakat Sipil: Sebuah Toolkit, ed. in Mufti Makaarim A., et al. (IDSPS-DCAF, 2009), 11.

5 CM. http://www.bin.go.id. 
разведки, психологической войны и диверсий. Затем их отрядили во все районы острова Ява с заданием искать помощи для защиты Республики и наблюдать за передвижениями противника. ${ }^{6}$

В начале мая 1946 г. вновь набранные агенты проходили специальную подготовку в районе города Амбарава [провинция Центральная Ява]. В результате примерно 30 молодых выпускников стали первой группой сотрудников Государственного секретного агентства Индонезии (Badan Rahasia Negara Indonesia, BRANI). Это агентство объединило разведку и ряд специальных подразделений, в том числе для операций за рубежом. ${ }^{7}$ Лубис создал BRANI 3 мая 1946 г., как общую структуру специальных подразделений, сформированных полевыми командирами и действующих по всей Яве. Лубис также выезжал за пределы Явы на корабле, чтобы организовать полевые части на Бали, Калимантане, Молуккских и Западных Малых Зондских островах, Сулавеси и Суматре. Лубис сам находил средства и ресурсы для проведения операций за рубежом в поддержку республиканской армии, которой не хватало оружия, боеприпасов и медикаментов. ${ }^{8}$

Гражданское Министерство обороны предложило Президенту Сукарно сформировать орган стратегической разведки «гражданского характера», неподконтрольный военным. В июле 1946 г. Министр обороны Амир Шарифуддин (Amir Sjarifuddin) пытался создать Оборонное бюро В (Badan Pertahanan B) во главе с бывшим комиссаром полиции. Затем, 30 апреля 1947 г., он объединил все разведывательные агентства под эгидой Министерства обороны. Несмотря на поддержку Президента Сукарно, BRANI в конце концов распустили и заменили на Bagian V (V отдел) Badan Pertahanan B. Bagian V [или KP V] был «маленьким подразделением» Badan Pertahanan $B$, не способным работать оптимально. После ухода Шарифуддина из Кабинета Bagian V распустили, и Лубис провел «чистку» разведки от членов Коммунистической партии Индонезии (КПИ, Partai Komunis Indonesia, PKI), набранных Шарифуддином. «Мадиунское восстание» 1948 г., подавленное армией, закончилось арестом и тайной казнью Шарифуддина. ${ }^{9}$

Когда в январе 1948 г. Кабинет Амира Шарифуддина пал [за несколько месяцев до Мадиунского восстания], правительство включило распущенную разведку Bagian V в состав І отдела Генерального штаба Армии (Bagian

6 CM. Ken Conboy, Intel Menguak Tabir Dunia Intelijen Indonesia (Pustaka Primata, 2008), 1-2. Английское издание - Ken Conboy, Intel Inside Indonesia's Intelligence Service (Equinox Publishing, 2004). См. также https://historia.id/militer/articles/ zulkifli-lubis-bapak-int Cerdas-indonesia-DrBXE.

7 CM. http://www.bin.go.id. BRANI произносится так же, как индонезийское слово «berani» (храбрый, смелый).

8 Conboy, Intel Inside Indonesia's Intelligence Service, 3-5.

9 Conboy, Intel Inside Indonesia's Intelligence Service, 7-8. См. также Hariyadi Wirawan, Evolusi Intelijen Indonesia, in Reformasi Intelijen Negara, ed. Andi Widjajanto (Pacivis UI-FES, 2005), 28-29. 
I Staf Umum Angkatan Darat, SUAD). Лубис вернулся к руководству и одновременно возглавил штаб Командования на Яве (Markas Besar Komando Djawa, MBKD-I). После передачи Нидерландами суверенитета разведывательная организация была преобразована в Разведку Министерства обороны (Intelijen Kementerian Pertahanan, IKP), а Лубис остался ее руководителем. В 1952 г. Лубис сформировал Информационное бюро Вооруженных сил (Biro Informasi Angkatan Perang, BISAP), отвечавшее за подготовку стратегической информации для Министра обороны и Начальника штаба Bооруженных сил генерала Симатупанга (Simatupang). Он также инициировал дальнейшее обучение разведчиков в Калиуранге, провинция Джокьякарта. ${ }^{10}$ BISAP считалось слишком слабым для выполнения задач стратегической разведки, что стало одной из причин «войны» Лубиса с главнокомандующим Сухопутных войск генералом Насутионом (Nasution), ${ }^{11}$ и Лубису пришлось больше заниматься «внутренней политикой» Вооруженных сил.

В том же году Вице-президент Мохаммад Хатта и Министр обороны Сри Султан Хаменгку Бувоно IX приняли предложение Центрального разведывательного управления (ЦРУ) США профессионально готовить кандидатов для индонезийской разведки на острове Сайпан, Филиппины. ${ }^{12}$ Эта негласная помочь США была организована через Бюро безопасности (Dinas Chusus, DC) - орган министерского уровня, координировавший операции Министерства обороны, а не через BISAP, которое Вице-президент и Министр обороны считали "ненадежным». Поэтому Бюро безопасности составило список из 50 гражданских, среди которых был произведен отбор в Центральной Яве, и 17 из них первыми прошли эту подготовку. В феврале 1953 г. они вернулись в Индонезию и обнаружили множество изменений. BISAP было распущено, Начальник штаба Сухопутных войск генерал Насутион - «смертель-

10 CM. Hendri F. Isnaeni, "Zulkifli Lubis, Bapak Intelijen Indonesia," Historia, February 2, 2016, https://historia.id/militer/articles/zulkifli-lubis-bapak-intelijen-indonesia-DrBXE.

11 Насутион - автор концепции Dwifungsi ABRI (Angkatan Bersenjata Republik Indonesia), или Двойной функции Вооруженных сил Республики Индонезия, представленной в 1958 г. и позднее утвержденной при администрации Сухарто. Согласно этой концепции, ВС РИ не находятся под гражданским контролем, но в то же время не доминируют и не становятся военной диктатурой. 17 октября 1952 г. Насутион [и генерал Симатупанг] подняли войска, окружили Президентский дворец в знак протеста против гражданского вмешательства в военные дела и направили на дворец пушки. Сукарно вышел из Президентского дворца для встречи с демонстрантами и в конце концов убедил военных и гражданских вернуться домой. Итогом этого инцидента стала отставка Насутиона в декабре 1952 г. 7 ноября 1955 г., после трех лет в изгнании, Насутиона вновь назначили на прежний пост Начальника штаба Сухопутных войск (Kepala Staf Angkatan Darat), а Лубиса уволили.

12 См. http://www.bin.go.id. 
ный враг» Лубиса - уволен Президентом Сукарно. ${ }^{13}$ Лубис был назначен заместителем Начальника штаба Сухопутных войск (Kepala Staf Angkatan Darat); после роспуска BISAP все военные службы включили в состав соответствующих разведывательных организаций. Бюро безопасности определило этих выпускников с Сайпана в Фирму Ксатрия (Ksatria Graha). Они проводили разведывательные операции под руководством Бюро безопасности. ${ }^{14}$

5 декабря 1958 г. Президент Сукарно сформировал Совет по координации разведки (Badan Koordinasi Intelijen, BKI) и назначил его главой полковника Пирнгади. Это ведомство должно было вновь организовать координацию всех разрозненных частей разведки, чтобы укрепить власть Президента, которому приходилось бороться с восстаниями и нападками гражданской и военной оппозиции. Кроме того, 10 ноября 1959 г. ВКІ реорганизовали в Центральное разведывательное агентство (Badan Pusat Intelijen, BPI) со штаб-квартирой на ул. Мадиун в Джакарте во главе с д-ром Субандрио, который также был Министром иностранных дел и доверенным лицом Президента. В 1960-х гг. и до конца эры «Старого порядка» (Orde Lama) влияние Субандрио на ВРІ было очень сильным, в свете противоборства коммунистической и некоммунистической идеологий в армии, включая разведку. ${ }^{15}$

К ноябрю 1965 г. ВPI стал инструментом в борьбе за интересы Субандрио, якобы защищавшим Президента Сукарно от планировавшегося переворота Генерального совета (Dewan Jenderal) Армии. Военное руководство решительно отвергало обвинения в сотрудничестве Армии с американской и британской разведкой для свержения Президента Сукарно, который считался защитником КПИ, «расчищавшим политическое пространство» для этой партии. 30 сентября 1965 г. семь офицеров Сухопутных войск в Джакарте и два в Центральной Яве стали жертвами нападений «Движения 30 сентября». Быстро взять ситуацию под контроль после этого события означало «конец политической карьеры Субандрио и КРИ». Контрудар Армии был нанесен под командованием генерал-майора Сухарто по приказу Президента Сукарно от 11 марта 1966 г. (Surat Perintah 11 Maret, Supersemar) «восстановить безопасность», включая чистку в BPI.

13 Согласно другой версии, инцидент 17 октября [первый открытый конфликт между армией и гражданскими политиками] спровоцировала сессия Временного совета народных представителей (Dewan Perwakilan Rakyat Sementara, DPRS), обсуждавшая модернизацию Сухопутных войск, что Насутион и Симатупанг считали внутренним делом их руководства. 17 октября 1952 г. офицеры Штаба Сухопутных войск вместе с несколькими региональными командирами пришли во дворец, чтобы встретиться с Президентом Сукарно и попросить его взять власть в свои руки и распустить временный парламент. Сукарно не уступил давлению военных и Насутион, как высший офицер Штаба Сухопутных войск, ушел в отставку. См. Kisenda Wiranatakusumah, Civil-Military Relations in the Late Suharto Era, Thesis (Naval Postgraduate School, 2000), 17-21.

14 Conboy, Intel Inside Indonesia's Intelligence Service, 9-14.

15 CM. http://www.bin.go.id. 
Армия «взяла под контроль» $\mathrm{BPI}$, назначив бригадного генерала Сугихарто и.о. главы BPI в декабре 1965 г. Ранее, в ноябре, он был повышен до Начальника разведки Сухопутных войск вместо бригадного генерала Сисвондо Пармана - одного из офицеров, убитых при попытке похищения 30 сентября. С 18 по 21 марта 1966 г. несколько руководителей BPI, считавшихся сторонниками КПИ, были арестованы и приговорены к тюремному заключению. Самого Субандрио судили и приговорили к смертной казни (он был заключен в тюрьму, но приговор так и не привели в исполнение).

Теоретически тип отношений между разведкой и государством, сформированный в этот период, является «политической разведкой». Даже в 19501959 г. индонезийской разведке не хватало внимания из-за нестабильной политической ситуации. После официального признания Республики Индонезия 15 августа 1950 г. разведслужбы Индонезии были восстановлены. Индонезии пришлось проводить разведывательные операций для противодействия внутренним угрозам. Однако из-за доминирования военных в предыдущий период политическая разведка была создана только в 1958 г., когда Сукарно сформировал BKI, позднее реорганизованный в BPI. В 1950 1958 г. военная разведка все еще доминировала в оперативной работе разведслужб, хотя и не имела задач противостоять конкретной внешней угрозе. Процесс политизации начался в начале 1952 г., когда Начальник штаба Вооруженных сил Симатупанг сформировал BISAP как разведывательное агентство для обеспечения деятельности своего аппарата и Министерства обороны. Однако из-за организационной слабости и ограниченных средств и ресурсов BISAP мало что могло сделать и было распущено в следующем году. ${ }^{16}$

\section{Разведка Нового порядка (Orde Baru), 1965-1998 гг. ${ }^{17}$}

Генерал-майора Сухарто назначили руководителем Оперативного командования по восстановлению законности и порядка (Komando Operasi Pemulihan Keamanan dan Ketertiban, КОРКАМТ(В), сформированного через три дня после нападений «Движения 30 сентября». Он принял решительные меры для восстановления безопасности и «зачистки» сторонников и членов КПИ, в том числе в разведке. Сухарто, реально понимавший важность функций разведки и необходимость действовать быстро, сформировал разведгруппы (Satuan Tugas Intelijen, STI) во всех военных округах (Komando Daerah Militer, KODAM). Разведгруппы оказывали поддержку операциям KOPKAMTIB под началом командующих всех военных округов, проводя расследования и занимаясь разведкой.

16 CM. Andy Widjajanto and Artanti Wardhani, State-Intelligence Interaction 1945-2004 (Pacivis UI \& FES, 2008), 70-71.

17 Администрация Сухарто называла этот период Новый порядок (Orde Baru), пришедший на смену эре Президента Сукарно, которую она называла Старый порядок (Orde Lama). 
Структура партизанских действий войны за независимость после 1945 г., разделившая территорию Индонезии на военные округа, была принята как проявление концепции «среднего пути» Насутиона для обеспечения военных потребностей «искоренения» КПИ и политического контроля, как формы Dwifungsi ABRI. На каждом уровне гражданского управления есть военный элемент, входящий в так называемый Совет регионального руководства (Musyawarah Pimpinan Daerah, Muspida), обычно возглавляемый военными. Эта схема сохранилась по сей день (см. Таблицу 1). В большинстве городов и провинций губернаторы и мэры назначаются Президентом и обычно являются офицерами $A B R{ }^{18}{ }^{18}$ Явным преимуществом, полученным Сухарто от такого использования военных округов, стала определенная власть и деятельность военной разведки, которую может проводить эта структура, что позволяло Сухарто «узнавать» о «любых угрозах» даже на уровне деревни.

22 августа 1966 р. Сухарто при поддержке Президента Сукарно создал Государственное командование разведки (Komando Intelijen Negara, KIN) во главе с бригадным генералом Йога Сугомо (Yoga Sugomo). Глава KIN напрямую подчинялся Сухарто. Как агентство стратегической разведки, BPI, уже находившееся под контролем Сухопутных войск, было влито в KIN, также имевшее отдел специальных операций (Operasi Khusus, Opsus) во главе с подполковником Али Муртопо (Ali Moertopo) и его заместителями Леонар-

Таблица 1. Параллельные гражданские и военные структуры территориального управления. ${ }^{19}$

\begin{tabular}{|l|c|}
\hline \multicolumn{1}{|c|}{ ВОЕННАЯ СТРУКТУРА } & $\begin{array}{c}\text { ГРАЖДАНСКАЯ } \\
\text { АДМИНИСТРАЦИЯ }\end{array}$ \\
\hline KODAM (Командование военного округа) & Провинция \\
\hline КOREM (Командование военного подокруга) & Регион \\
\hline КODIM (Командование военного района) & Район \\
\hline КОRAMIL (Командование военного подрайона) & Подрайон \\
\hline ВABINSA (Комендант по развитию деревни) & Деревня \\
\hline
\end{tabular}

18 CM. Salim Said, Soeharto's Armed Forces: Problems of Civil Military Relations in Indonesia (Pustaka Sinar Harapan, 2006), 20-22.

19 CM. Said, Soeharto's Armed Forces, 22. 
дусом Беньямином Мурдани ${ }^{20}$ и Алоизиусом Сугиянто. ${ }^{21} \mathrm{KIN}$ стало новым агентством, докладывавшим по вопросам национальной и международной безопасности, включая политические, социальные, экономические и иные вопросы, касающиеся военной безопасности в стране и за рубежом. В начале карьеры Сухарто сам возглавлял эту организацию, назначая своих доверенных лиц на ключевые должности. Меньше чем через год, 22 мая 1967 г., Сухарто официально став Президентом, издал Президентский указ (Keppres), переименовав KIN в Национальный совет координации разведки (Badan Koordinasi Intelijen Negara, BAKIN). Генерал-майор Судриго стал первым руководителем BAKIN. Как и в $K I N$, высший эшелон состоял в основном из офицеров, но в среднем и нижнем звене были и гражданские чиновники. BAKIN создавали как гражданский орган, но в реальности высшие офицеры сохраняли сильные позиции в руководстве BAKIN.

Кроме военного режима, Orde Baru был отмечен проникновением разведки во все аспекты жизни людей. BAKIN стал органом стратегической разведки по всем вопросам, кроме КОРКАМТІB, проводившего чистку КПИ и ее сторонников в военных округах и разведгруппах. Opsus, созданный как разведорган для захвата Западного Папуа у Нидерландов и борьбы с Малайзией, позднее использовали для слежки за общественной, политической и религиозной жизнью общества, особенно - людей и групп, которые потенциально могли выступать против правительства Сухарто, а также для проведения разведывательных операций против угрозы сепаратизма в Ачехе, Папуа и Восточном Тиморе. ${ }^{22}$ Таким образом, военные органы, приданные гражданскому правительству, в конечном счете выполняли разведыватель-

20 Мурдани известен как военный офицер, много занимавшийся разведкой, его личность часто называют таинственной. Мурдани непосредственно участвовал в военной операции после угона рейса 206 индонезийской авиакомпании Garuda в аэропорту Донмуанг, Бангкок, Таиланд, 28 марта 1981 г., что позднее назвали первым угоном самолета в истории индонезийской авиации и первым терактом джихадистов в Индонезии. Многие также считают его ответственным за инцидент в районе Танджунг Приок (Tanjung Priok, нападение на прихожан мечети) и таинственные расстрелы в 1980-х гг., когда сотни людей, считавшихся преступниками, находили мертвыми на улицах. На правительственных должностях, кроме службы командующим ABRI в 1983-1988 гг., он также был Министром обороны и безопасности и командующим КОРКАМТІВ.

21 Годовщину создания KIN, ныне BIN, празднуют 22 августа, http://www.bin.go.id.

22 Мурдани, имевший опыт помощника Министра обороны и безопасности по разведке, помощника Командующего КОРКАМТІВ по разведке, главы Центра стратегической разведки (Pusat Intelijen Strategis, Pusintelstrat) и заместителя руководителя BAKIN, плотно занимался вопросом деколонизации Восточного Тимора. В августе 1975 г. Мурдани начал отправлять индонезийских солдат под видом добровольцев для проникновения на Восточный Тимор. Ситуация обострилась 28 ноября 1975 г., когда Fretilin провозгласил независимость Восточного Тимора. Разведывательные операции прекратились, вместо них началась военная операция - Operasi Seroja (военное вторжение). Хотя вторжение не было разведывательной операцией, Мурдани продолжал принимать в ней участие, теперь как разработчик планов вторжения и организатор разведки в ходе операции. 
ную «функцию» защиты от того, что при Orde Baru называли скрытой опасностью и угрозами безопасности. В этой связи массово происходили случаи насилия и нарушения прав человека, изменившие общественно-политический климат (например, ограничение возможностей выражения, аресты и убийства политических активистов и лидеров оппозиции), а также общественную и культурную жизнь, экономику (так, у людей принудительно забирали землю, уничтожали окружающую среду и леса в «сопровождении» военных и разведывательных органов).

Стратегия Сухарто в 1970-х гг. заключалась в создании «конкуренции» между разными органами, чтобы они не могли «объединиться» против Сухарто, что закончилось прямым подчинением ему всех разведслужб. Хотя Сухарто назвал BAKIN агентством стратегической разведки, он не распустил в то же время KOPKAMTIB и Opsus. Сухарто также «укрепил» роль «помощника по разведке» в Министерстве обороны и безопасности, который должен был одновременно руководить территориальными подразделениями военной разведки, подчиненными ABRI (Командующий Вооруженных сил Республики Индонезия), КОРКАMTIB и BAKIN, которые часто выполняли пересекающиеся операции и даже конкурировали, защищая интересы Сухарто. Мурдани, которому поручили возглавить Центр стратегической разведки Министерства обороны и безопасности, поставив его во главе $A B R I$ в январе 1983 г., создал Агентство стратегической разведки (Badan Intelijen Strategis, BAIS) и построил международную сеть, контролируя военных атташе в посольствах Индонезии. Имея хорошее бюджетное финансирование и мощную сеть в стране и за рубежом, BAIS в конце концов стало разведывательным агентством, которое выделялось и превосходило другие агентства. ${ }^{23}$

BAIS и само критиковали за формирование одностороннего представления об угрозе национальной безопасности, представляя гражданских из разных критически настроенных групп как угрозу. Используя этот термин для обозначения групп, не согласных с идеологией Pancasila- официальной идеологией государства согласно Конституции - BAIS разделяет источники угрозы на следующие категории:

1) Леворадикальные группы: имеющие социал-демократическую или коммунистическую (марксистскую) ориентацию;

2) Праворадикальные группы, а именно политические организации, продвигающие дискурс исламского права; и

3) Иные радикальные группы, а именно НПО, недовольные и разочарованные правительством, такие, как Imparsial и KontraS (две из

${ }^{23} \mathrm{CM}$. Aleksius Jemadu, "State Intelligence Agency," in 2007 Security Sector Reform Almanac, ed. Beni Sukadis (Lesperssi-DCAF, 2007), 92-93. См. также Widjajanto and Wardhani, State-Intelligence Interaction, 79-93. 
десятков индонезийских НПО, выступающих за права человека и реформирование сектора безопасности). ${ }^{24}$

Отношения Сухарто и Мурдани к концу 1980-х гг. становились все более напряженными. Сухарто, знавший о появлении политического давления в пользу демократии в стране и за рубежом, изменил стратегию сохранения власти, «охватив» исламские организации, которые он сумел вырастить в Индонезийской ассоциации мусульманской интеллигенции (Ikatan Cendikiawan Muslim Indonesia, ICMI). Тем самым Сухарто выработал новый «зеленый» стиль $A B R I$, чтобы устранить впечатление о своем антиисламизме. При командующем $A B R I$ генерале Файсале Танджунге - мусульманине и стороннике Сухарто, назначенном в мае 1993 г. - BAIS распустили и заменили на Разведывательное агентство ABRI (Badan Intelijen ABRI, BIA) с многочисленными перестановками кадров, чтобы стереть влияние Мурдани в индонезийском разведывательном сообществе. ${ }^{25}$ Сухарто намеренно назначил в BAKIN генерал-лейтенанта Мутоджиба, офицера TNI, не слишком влиятельного и непокорного. Хотя BAIS пыталось мобилизовать исламские организации путем объединения военных и интеллектуальных мусульманских элит в ICMI, ориентация BAKIN сместилась в сторону слежки за движениями за демократию и политическими активистами, все активнее выступавшими против правления Сухарто в 1990-х гг. ${ }^{26}$ Ранее, в 1988 г., с закатом Мурдани, КОРКАМТІВ также реорганизовали в Национальное агентство по вопросам стабильности и координации (Badan Koordinasi dan Stabilitas Nasional, Bakorstanas). Следы Мурдани немедленно исчезли.

\section{Период реформы разведки после 1998 г.}

Когда Сухарто «ушел» с поста Президента в мае 1998 г. из-за давления политического движения за демократию и падения поддержки гражданской политической элиты, его преемники не могли сразу в корне изменить структуру и культуру разведслужб. Стоит заметить, что люди Сухарто кишели в ABRI и всех разведывательных агентствах, де-факто оставаясь лояльными бывшему, а не нынешнему правителю. Единственным вариантом было назначение руководителями «верных людей». В BAKIN Президент Б.Ю. Хабиби, сменивший Сухарто, выбрал генерал-лейтенанта Маулани. Президент Абдуррахман Вахид, избранный в 1999 г., назначил генерал-лейтенанта Арие Дж. Кумаата (некоторые источники утверждают, что он был «вынужден» назначить Арие, потому что не было другой лояльной фигуры, способной контролировать BIN, где по-прежнему доминировали военные). Президент Мегавати Сукарнопутри, избранный в 2001 г., назначил генерал-лейте-

${ }^{24}$ CM. Rizal Darma Putra, "Strategic Intelligence Agency (BAIS)," in 2007 Security Sector Reform Almanac, 106-107.

25 CM. Salim Said, Soeharto's Armed Forces, 86.

26 Jemadu, "State Intelligence Agency," 93. 
нанта Хендроприйоно. Затем BAKIN переименовали в BIN, с главными функциями и задачами, определенными Президентским указом № 1032001 г.

Пост руководителя BIN скорей политическим, чем профессиональным. Традиция выбора доверенного лица Президента сохранилась и при Президенте Сусило Бамбанге Юдойоно, и при Президенте Джоко Видодо (Джокови), который тоже выбирал бывших высокопоставленных офицеров полиции. Президент Юдойоно назначил генерал-майора Сиямсира Сиригара, ${ }^{27}$ генерала полиции Сутанто и генерал-лейтенанта Марсиано Нормана. Президент Джокови назначил отставных старших офицеров, генерал-лейтенанта Сутийосо и генерала полиции Буди Гунавана, которые служат до сих пор.

Как указано выше, режим Сухарто, павший из-за давления с разных сторон, ${ }^{28}$ оставил новому правительству одну проблему: военные структуры, по-прежнему лояльные Сухарто. Маулани, возглавлявший BAKIN при Президенте Хабиби, в интервью для СМИ выразил разочарование Сухарто гражданской элитой, которая «предала» его, приведя слова Сухарто: «Я лелеял и продвигал их с самого начала их карьеры, но когда мне действительно понадобилась их поддержка, они отреклись от меня ${ }^{29}$ Изменение отношения армии, лояльной Сухарто, для поиска механизма реформирования сектора безопасности с участием военных, полиции и разведки может быть лишь постепенным и полным компромиссов, без полного их отстранения от политической жизни и государственной политики, что по сути является прерогативой гражданской политической власти.

$B A K I N$, позднее переименованное в $B I N$, по-прежнему находится под контролем военных, особенно из-за их возможной причастности к ряду социальных конфликтов и актов насилия, произошедших после 1998 г., в чем видят проявление «гнева» Сухарто. В то время сформировались три точки

27 Последнее звание Сиригара перед отставкой - генерал-майор, должность - руководитель ВІА. Он был назначен после отставки и поэтому не мог получить повышения.

28 Сукарди Ринакит упоминал несколько причин падения Сухарто, в том числе: 1) Международное политическое давление, особенно со стороны США и МВФ. Это давление использовало вопрос нарушения прав человека, похищение активистов и продолжение насилия в Ачехе, Восточном Тиморе и Папуа. Это давление также привело к ухудшению экономической ситуации; 2) Заговор элит, особенно руководства ICMI, которое отказало в поддержке, мобилизовало демонстрантов и призвало руководство Народного консультативного конгресса (Majelis Permusyawaratan Rakyat, MPR) попросить Сухарто уйти в отставку; 3) Сдвиг в поддержке военных от «красно-белых» (националистов, символизируемых цветом флага Индонезии) к «зеленым» (близким к исламским политическим группам). В крайних проявлениях эта ситуация вылилась в борьбу между фракциями «Политический ислам» и Pancasila, приведшую к беспорядкам в мае 1998 г., за несколько дней до отставки Сухарто. См. Sukardi Rinakit, The Indonesian Military After the New Order (ISEAS, 2005), 3-4.

29 Rinakit, The Indonesian Military After the New Order, 5. 
зрения. Первая: обвинения в том, что все формы хаоса создавались организациями, лояльными "старому порядку», широко и систематично, с ужасными массовыми последствиями. Вторая: хотя давление нового правительства на аппарат безопасности для преодоления этих нарушений безопасности усилилось, предпринятые меры были медленными и не оптимальными. ${ }^{30}$ Говорили о намеренном непринятии мер против этого хаоса, вновь из-за лояльности «старому порядку». Третья точка зрения утверждает, что этот хаос является стратегией усиления служб безопасности, чтобы утвердиться в глазах гражданского правительства, и когда гражданское правительство попросит этот аппарат действовать, начнутся переговоры об их весе, давлении реформ и о том, что «можно» и чего «нельзя» делать.

Попытка добиться подотчетности разведки - нелегкая задача. Дело о смерти правозащитника Мунира Саида Талиба ${ }^{31}$ при перелете из Индонезии в Амстердам 7 сентября 2004 г. - возможной «разведывательной операции» после реформ 1998 г. - зависло. Судили лишь одного исполнителя, которого объявили «агентом разведки» и признали виновным, и одного из руководителей BIN, который общался с агентом, но в конце концов был

30 При Президенте Абдуррахмане Вахиде происходили этнические конфликты на Калимантане и религиозные конфликты на Молуккских островах. Мой опыт работы в составе одного из источников информации для Дворца в то время показывает, что Президент не имел надежной информации с мест, не мог контролировать движения военных, усугублявшие конфликт, превращая его в поле для бизнеса, и не сумел максимально использовать эффект разведывательных операций для предотвращения и создания нормальных условий. Образ Президента как защитника религиозных и этнических меньшинств, способного провести реформу, «пошатнули» механизмы организации работы правительства того времени. Показательным примером является появление военизированной группировки Ласкар Джихад (Laskar Jihad) во главе с участниками афганской войны на Молуккских островах для участия в религиозном конфликте. Президент твердо приказал всем службам безопасности и разведки не допустить их появления, но не все было сделано, говорили даже, что им специально оставили лазейку. В конце концов конфликт на Молуккских островах стал одним из путей появления террористических движений Джемаа Исламия и Аль-Каида, учебного лагеря и создания новых ячеек и сетей, посеяв семена радикальных движений и терроризма, которые живут и ширятся в Индонезии по сей день.

31 Мунир Саид Талиб - правозащитник-идеалист, защищавший жертв насилия и готовый выступить против военных и полиции в борьбе за права этих жертв. Угрозы убийства и запугивания, чтобы вынудить Мунира прекратить свою деятельность во главе KontraS и Imparsial (две главные правозащитные организации Индонезии, созданные им) - не новость, включая слежку и попытки представителей сил безопасности прямо или опосредованно помешать его правозащитной деятельности. Перед вылетом в Амстердам Мунир говорил, что получил телефонный звонок и просьбу «агента» (которого позднее выявили по результатам полицейского расследования как исполнителя) о встрече на рейсе Джакарта-Сингапур перед пересадкой до Амстердама. Мунир сам сообщил об этом семье и друзьям перед смертью. 
оправдан. В раскрытии этого дела по сей день нет сдвигов, вопрос и обвинения разведывательных операций остаются тайной. Это дело - еще одно свидетельство нападок и попыток закрыть рот оппозиционным организациям и правозащитникам, которых не должно было быть в эпоху реформ. Такие случаи дают понимание того, что новые разведывательные органы и операции невозможны, если мы основываемся на организационных реалиях и имеющейся правовой базе, потому что они являются продуктом авторитарной политики «Нового порядка». Беспокоить должны не новые нормы, которые сейчас продвигают, а нынешнее отсутствие норм демократического контроля за разведкой.

Закон о национальной разведке наконец появился в конце 2011 г., через 12 лет после начала реформы. Этот закон, принятый, в частности, в результате давления после убийства правозащитника Мунира, действительно прогрессивный и может помочь успеху реформы разведки, исключив повторение и традиции авторитарной разведки в духе «Нового порядка». Разведслужбы должны отказаться от старой парадигмы понимания угроз и обратить пристальное внимание на такие новые вызовы, как мировой терроризм. Нужно усиливать национальную религиозную политику. Разведка должна способствовать созданию мирного мира, свободного от новых угроз, таких, как разрушение окружающей среды и вспышки болезней.

\section{Законодательство, государственное управление и реформа разведки}

С начала реформ 1998 г. давление гражданского общества в пользу реформирования разведки было недостаточно сильным. Кроме таких структурных демократических изменений, как демократизация и изменение или отмена статей конституции и авторитарных законов, главные проблемы сектора безопасности решались поверхностно. Реформирование сектора безопасности началось с разделения двух организаций, ранее входивших в ABRI - Национальной армии Индонезии (Tentara Nasional Indonesia, TNI) и Национальной полиции Индонезии (Kepolisian Negara Republik Indonesia, Polri). Другими ключевыми вопросами были нарушения прав человека при "Новом порядке», ликвидация двойной функции $A B R I$, освобождение политзаключенных «Нового порядка» и восстановление экономики после 1997 г. $^{32}$

Индонезийский университет Pacivis обращает внимание на задачу избежать ухудшения безопасности и конфликтов, что вынуждало гражданскую элиту к компромиссу - не слишком «давить» на военных, ибо они нужны

32 Чтобы понять динамику движения гражданского общества за реформу сектора безопасности, особенно армии, полиции и разведки в Индонезии в 1998-2006 гг., cM. Mufti Makarim A. and Sri Yunanto, eds., Efektivitas Strategi Organisasi Masyarakat Sipil Dalam Advokasi Reformasi Sektor Keamanan di Indonesia 1998-2006 (IDSPS, 2008). 
для восстановления безопасности. Такая необходимость в «военных» проявилась в назначении офицеров - Маулани, Арие Кумаата, Хендроприйоно - руководителями BAKIN (позднее BIN). ${ }^{33}$ В то время в Ачехе, Восточном Тиморе и Папуа существовала серьезная угроза сепаратизма, общественные конфликты на религиозной и этнической почве возникали на Молуккских островах, Сулавеси и Калимантане.

В эпоху Сукарно проблема организации разведки заключалась в системе координации BKI на уровне руководства организаций (например, руководителя Генеральной прокуратуры и военного руководства), не занимавшемся технической координацией деятельности. На практике руководители часто назначали чиновников, некомпетентных принимать решения, или низкого ранга. В результате $B K I$, созданное Постановлением Правительства № 64 от 1958 г., просуществовало меньше года. Затем Президент Сукарно сформировал ВРІ Постановлением Правительства № 8 от 1959 г. и предоставил ему не только координационные полномочия, но и право проводить разведывательные операции. Субандрио, как глава ВРI и одновременно Первый заместитель Премьер-министра (эквивалентно званию генерал-полковника) и Министр иностранных дел, должен был осуществлять действенный контроль над внутренней разведкой, но после инцидента 30 сентября Субандрио отстранили от должности и судили, а Президент Сукарно реорганизовал BPI в KIN во главе с генерал-майором Сухарто ${ }^{34}$ (который позднее низверг Сукарно). KIN была создана Президентским указом № 1811966 г. и позже реорганизована в BAKIN Президентским указом № 701967 г.

Как и BPI, BAKIN не только координирует разведывательные и военные службы министерства, но и проводит разведывательные операции. Смена на $B I N$, которое сначала регулировалось на основе Президентского указа № 5 от 2002 г., также сопровождалась сохранением прежних полномочий. Как и в предыдущих случаях, создание эффективного BIN сталкивалось с определенными трудностями, например, конкуренцией ведомственных разведслужб. Кроме того, его организационный статус был слабым - в то время как BIN руководствовалось Президентским указом, институты и министерства, которые оно должно было координировать, были созданы Законом и имели более «высокий» статус. ${ }^{35}$

Процесс разработки закона о разведке, предложенного в пакете реформ 1998 г., шел сложно. Были аргументы за и против этого закона, проект, предложенный правительством, резко критиковали. Тем не менее проект предусматривал правоохранительные полномочия разведывательного аппарата, с исключительным правом проведения операций гражданской стратегической разведки. Ему, однако, недоставало положений о подотчетности и

33 Widjajanto and Wardhani, State-Intelligence Interaction, 93.

34 CM. Irawan Sukarno, Aku 'Tiada' Aku Niscaya Menyingkap Lapis Kabut Intelijen (Yayasan Pustaka Obor Indonesia, 2011), 53-55.

35 Sukarno, Aku 'Tiada' Aku Niscaya Menyingkap Lapis Kabut Intelijen, 57-59. 
профессионализме разведки. Для гражданского общества проект, поданный для обсуждения в парламенте, был настолько же легитимен, как и разведывательные организации и операции, проводимые при авторитарном правлении.

К счастью, при обсуждении во Временном совете народных представителей были внесены изменения и исправления, хотя не все они были умеренными и учитывали предложения НПО. Моменты, которые требовали исправления, когда принимался закон, затем были оспорены в Конституционном суде. И хотя в конце концов гражданское общество «проиграло» в этом судебном споре, этот пример символизирует надежду на участие в создании разведки, соответствующей принципам демократии и верховенства права, принятым в Индонезии. Благодаря наличию этого Закона положение, организация и операции разведки описаны и могут контролироваться обществом и парламентом. В будущем стоит задача контролировать исполнение закона, включая оценку процесса реформы BIN и разведывательных организаций на уровне министерства и организации (включая армию и полицию) с тем, чтобы они работали в соответствии с существующими нормами права.

\section{В заключение: Актуальные проблемы индонезийской разведки}

С 1945 г. и по сей день государственная разведывательная служба шесть раз меняла свое официальное название: BRANI (Государственное секретное агентство Индонезии), BKI (Совет по координации разведки), BPI (Центральное разведывательное агентство), KIN (Государственное командование разведки), BAKIN (Национальный совет координации разведки) и BIN (Государственное разведывательное агентство). Изменения проводились с целью улучшить и усилить эту организацию. Однако наша история показывает, что это не просто.

Разведка, как «первая линия обороны», должна быть адаптирована ко времени и угрозам. Развитие организации должно быть ориентировано на совершенствование, объединяющее пять аспектов; демократию и принципы верховенства права, профессионализм, адаптацию к развитию технологий, способность увидеть современные угрозы, и трансформацию предоставленных государством возможностей для достижения максимального результата.

Ираван Сукарно выразил интересную точку зрения: (индонезийская) разведка в будущем должна стремиться выиграть мир. Управление разведкой усложняется, так как появляются новые, значительно более сложные поля сражений. Нетрадиционная война имеет более сложные измерения, стратегию, динамику, риски и масштабы; к ней нельзя подходить, полагаясь на одни лишь вооруженные силы, требуются и «гражданские силы», адаптированные к данному типу сражения. ${ }^{36}$

36 Sukarno, Aku 'Tiada' Aku Niscaya Menyingkap Lapis Kabut Intelijen, 208-210. 
В заключение хочется выделить три главных момента. Во-первых, опыт милитаризации разведки и использования разведслужб в интересах элиты должен стать уроком при реорганизации и реформировании разведки в профессиональную службу, независимую от политики и служащую только интересам государства. Во-вторых, с искушением вернуться к прежней тактике и ориентации на внутренние угрозы, особенно для наступления на политическую оппозицию и контроля общества, надо бороться. Это давало плохие прецеденты и не поможет формированию современной разведывательной организации. И в-третьих, проблемы, стоящие перед Индонезией, включая пандемию Covid-19, свирепствующую сейчас во всем мире, следует использовать для подтверждения гибкости разведывательной работы. Образ «Intel Melayu» (агента разведки, который может только пугать граждан, показывая «корочки»), по-прежнему присущий агентам нашей разведки, нужно менять. Когда это произойдет, обеспокоенность общественности статусом Президента как единственного клиента BIN и политизацией этой организации исчезнет.

\section{Отказ от ответственности}

Выраженные здесь взгляды являются исключительно взглядами автора и не отражают точку зрения Консорциума оборонных академий и институтов изучения безопасности ПрМ, участвующих организаций или редакторов Консорциума.

\section{Благодарность}

Журнал Connections: The Quarterly Journal, Vol. 20, 2021 издается при поддержке правительства США.

\section{Об авторе}

Муфти Макарим А. - эксперт в области политики, обороны и безопасности В Исполнительном бюро Президента Республики Индонезия с января 2020 г. Ранее, кроме поста аналитика и консультанта по вопросам обороны и безопасности, Муфти занимался правозащитной деятельностью, исследованиями и помощью организациям гражданского общества в реформировании сектора безопасности, изучении конфликтов, защите прав человека и борьбе с терроризмом. Принимал участие в работе KontraS (Комиссия по исчезновениям и жертвам насилия) в 1999-2007 гг. и IDSPS (Институт исследования обороны, безопасности и мира) в 2007-2013 гг., когда индонезийские НПО оставили след в реформировании служб безопасности, включая разведку, а также гражданских органов власти в рамках демократизации и реформ в Индонезии. С 2013 г. Муфти сосредоточился на профессиональном консультировании и исследованиях для правительственного, неправительственного и частного сектора.

Электронная почта: makarimalahlaq@gmail.com 